DOI https://doi.org/10.36059/978-966-397-117-9/159-178

\title{
ACTIVITIES OF INTERNATIONAL ORGANIZATIONS IN THE FIELD OF EMPOWERMENT OF WOMEN, GENDER EQUALITY
}

\section{Kaminska N. V.}

\section{INTRODUCTION}

Gender equality is not only a fundamental human right, but a necessary foundation for a peaceful and successful world. Providing women and girls with equal access to education, health care, decent work, and representation in political and economic decision-making processes will fuel sustainable economies and benefit societies and humanity at large. However, gender inequality is still deeply ingrained in every society. Women suffer from violence, manifestation of professional discrimination, gender segregation of work, and so on. They are not sufficiently involved in the maintenance of peace and security within the framework of national, regional and international institutions and mechanisms for preventing, regulating and resolving conflicts.

In modern science, the issue of gender identity questioned representatives of different sciences: philosophy, sociology, medicine, jurisprudence etc. For example, it includes the work of such authors as S. Breus, A. Gorina, K. Kirichenko, C. Bem, I. Malkina, O. Grednovska, A. Kopêv, N. Romanova, A. Šhaliganova. In recent years, gender problems associated with the issue opportunities, human rights and nondiscrimination (J. Rawls, B. Weiss, M. Vitruk, G. Bekker, J. Robertson, T. Loenen, D. Harris, I. Zvaak, M. de Salvia, G. Christy).

Therefore, it is necessary to study the work of such international organizations as the United Nations that concerning providing gender equality and empower all women and girls and and NATO activities, their impact on Member States, which in turn changes the peace and security policy in general.

Task: according to the purpose of our research describe the history and evaluate the work of the United Nations,identify the impact of the United Nations on the achievements of the North Atlantic Treaty 
Organization and inquire into activities of the North Atlantic Treaty Organization, theirs cooperation.

\section{History and work of the United Nations}

The United Nations is an international organization founded in 1945. It is currently made up of 193 Member States. The mission and work of the United Nations are guided by the purposes and principles contained in its founding Charter. Due to the powers vested in its Charter and its unique international character, the United Nations can take action on the issues confronting humanity in the 21 st century, such as peace and security, climate change, sustainable development, human rights, disarmament, terrorism, humanitarian and health emergencies, gender equality, governance, food production, and more ${ }^{1}$.

Also provides a forum for its members to express their views in the General Assembly, the Security Council, the Economic and Social Council, and other bodies and committees. By enabling dialogue between its members, and by hosting negotiations, the Organization has become a mechanism for governments to find areas of agreement and solve problems together.

The United Nations advocates values that are the cornerstone of this emerging era: freedom, justice and the peaceful resolution of disputes; better standards of living; equality and tolerance and human rights. In fact, a world of complex and global challenges is exactly the environment in which the United Nations should thrive, because these are challenges that no country can resolve on its own. Terrorism and organized crime transcend state borders. Diseases such as AIDS are spreading globally, destroying human lives and disrupting economic activities. Climate change and environmental degradation pose major challenges and not only to future generations. Inequality and poverty can lead to instability and conflict that can quickly engulf entire regions.

Today, the United Nations is doing more to translate its ideals into real, measurable change than ever before. That is why, as the world looks to the United Nations for solutions, we must, in turn, find new and better ways of working. We must find ways to deliver more fully on our promises. We must be open to new approaches and ideas, and have the courage to question our traditional way of doing things. And, above all,

${ }^{1}$ Overview. Retrieved from http://www.un.org/en/sections/about-un/overview/index.html 
we must get ordinary people everywhere to trust our Organization, and to become more engaged in its work ${ }^{2}$.

Promotion of equality between women and men and the empowerment of women is central to the work of the United Nations. Gender equality is not only a goal in its own right, but is also recognized as a critical means for achieving all other development goals, including the Millennium Development Goals. Eradicating poverty and hunger, achieving universal primary education and health for all, combating HIV/AIDS and facilitating sustainable development all require systematic attention to the needs, priorities and contributions of women as well as men. The UN actively promotes women's human rights and works to eradicate the scourge of violence against women, including in armed conflict and through trafficking. Also adopts global norms and standards and supports follow-up and implementation at the national level, including through its development assistance activities.

The Commission on the Status of Women, under ECOSOC, monitors progress towards gender equality throughout the world by reviewing implementation of the platform for action that emerged from the Fourth World Conference on Women (Beijing, 1995). The Commission makes recommendations for further action to promote women's rights, and to address discrimination and inequality in all fields. The major contributions of the 45-member Commission during more than 60 years of activity include the preparation of and follow-up to four world conferences on women, including the Beijing Conference, and development of the treaty on women's human rights - the Convention on the Elimination of All Forms of Discrimination against Women.

The Committee on the Elimination of Discrimination against Women (CEDAW) monitors adherence to the Convention on the Elimination of All Forms of Discrimination against Women. The 23-member Committee holds constructive dialogues with states parties on their implementation of the Convention, based on reports they submit. Its recommendations have contributed to a better understanding of women's rights, and of the means to ensure the enjoyment of those rights and the elimination of discrimination against women.

The Division for the Advancement of Women, in the Department of Economic and Social Affairs, supports the efforts of the Commission on

\footnotetext{
${ }^{2}$ The United Nations Today. Retrieved from http://www.un.org/ar/geninfo/pdf/UN.today.pdf
} 
the Status of Women, the Economic and Social Council and the General Assembly to advance the global policy agenda for gender equality and strengthen the mainstreaming of gender perspectives in all areas of the United Nations.

The Special Adviser on Gender Issues and Advancement of Women provides advice to the Secretary-General. She plays a leadership and coordinating role within the UN on gender equality issues, and provides advice and support on gender mainstreaming in all areas of its work, as well as on improving the status of women within the Organization including the achievement of 50/50 gender balance. She provides support at the senior level to intergovernmental and expert bodies, including to the Security Council, on women, peace and security. The Special Adviser also chairs the Inter-Agency Network on Women and Gender Equality (IANWGE), which is comprised of the gender equality advisers and focal points from all parts of the UN system.

Beyond the Secretariat, all the organizations of the United Nations family address issues relating to women and gender in their policies and programmes.

The term "human rights" was mentioned seven times in the UN's founding Charter, making the promotion and protection of human rights a key purpose and guiding principle of the Organization. In 1948, the Universal Declaration of Human Rights brought human rights into the realm of international law. Since then, the Organization has diligently protected human rights through legal instruments and on-the-ground activities ${ }^{3}$.

The Commission on the Status of Women (CSW) is the principal global intergovernmental body dedicated to the promotion of gender equality and the advancement of women. UN Women, established in 2010, serves as its Secretariat.

Women and girls represent half of the world's population and therefore also half of its potential. But, today gender inequality persists everywhere and stagnates social progress. As of 2014, 143 countries have guaranteed equality between men and women in their Constitutions but 52 have yet to take this step ${ }^{4}$.

\footnotetext{
${ }^{3}$ Protect Human Rights. Retrieved from http://www.un.org/en/sections/what-we-do/protect-human-rights/ GENDER EQUALITY: WHY IT MATTERS. Retrieved from http://www.un.org/ sustainabledevelopment/wp-content/uploads/2016/08/5_Why-it-Matters_GenderEquality_2p.pdf ;
} 
Inequalities faced by girls can begin right at birth and follow them all their lives. In some countries, girls are deprived of access to health care or proper nutrition, leading to a higher mortality rate. As girls move into adolescence, gender disparities widen. Child marriage affects girls far more than boys. Globally, nearly 15 million girls under age 18 are married every year - or 37,000 each day.

Marrying young also affects girls' education. About one third of developing countries have not achieved gender parity in primary education. In sub-Saharan Africa, Oceania and Western Asia, girls still face barriers to entering both primary and secondary school.

Disadvantages in education translate into lack of access to skills and limited opportunities in the labour market. Women's and girls' empowerment is essential to expand economic growth and promote social development. The full participation of women in labor forces would add percentage points to most national growth rates - double digits in many cases.

Worldwide, 35 percent of women have experienced physical and/or sexual intimate partner violence or non-partner sexual violence. An estimated 133 million girls and women have experienced some form of female genital mutilation/cutting in the 29 countries in Africa and the Middle East, where the harmful practice is most common with a high risk of prolonged bleeding, infection (including HIV), childbirth complications, infertility and death.

Regardless of where you live in, gender equality is a fundamental human right. Advancing gender equality is critical to all areas of a healthy society, from reducing poverty to promoting the health, education, protection and the well-being of girls and boys. Investing in education programmes for girls and increasing the age at which they marry can return $\$ 5$ for every dollar spent. Investing in programs improving incomegenerating activities for women can return $\$ 7$ dollars for every dollar spent.

Recalling the commitments of the Beijing Declaration and Platform for Action (A/52/231) as well as those contained in the outcome document of the twenty-third Special Session of the United Nations General

Kaminska, N.; Romanova, N. Глобальні завдання ООН у сфері гендерної рівності. The United Nations worldwide goal: achieve gender equality and empowe http://elar.naiau.kiev.ua/ jspui/handle/123456789/5196 
Assembly entitled "Women 2000: Gender Equality, Development and Peace for the Twenty-First Century" (A/S-23/10/Rev.1), in particular those concerning women and armed conflict the Security Council at its 4213th meeting, on 31 October 2000 adopted Resolution 1325 (2000).

In this Resolution the Security Council urges Member States to ensure increased representation of women at all decision-making levels in national, regional and international institutions and mechanisms for the prevention, management, and resolution of conflict; encourages the Secretary-General to implement his strategic plan of action (A/49/587) calling for an increase in the participation of women at decisionmaking levels in conflict resolution and peace processes; urges the SecretaryGeneral to appoint more women as special representatives and envoys to pursue good offices on his behalf, and in this regard calls on Member States to provide candidates to the Secretary-General, for inclusion in a regularly updated centralized roster et cetera ${ }^{5}$.

Reaffirming its commitment to the continuing and full implementation of resolution 1325 (2000), 1612 (2005) and 1674 (2006) and recalling the Statements of its president of 31 October 2001 (Security Council/PRST/2001/31), 31 October 2002 (Security Council/PRST/2002/32), 28 October $2004 \quad$ (Security Council/PRST/2004/40), $27 \quad$ October $2005 \quad$ (Security Council/PRST/2005/52), 8 November $2006 \quad$ (Security Council/PRST/2006/42), 7 March 2007 (Security Council/PRST/2007/5), and 24 October 2007 (Security Council/PRST/2007/40) the Security Council accepted such resolution: Resolution 1820 (2008), adopted by the Security Council at its 5916th meeting, on 19 June 2008, Resolution 1888 (2009), adopted by the Security Council at its 6195th meeting, on 30 September 2009, Resolution 1889 (2009), adopted by the Security Council at its 6196th meeting, on 5 October 2009, Resolution 1960 (2010), adopted by the Security Council at its 6453rd meeting, on 16 December 2010, Resolution 2106 (2013), adopted by the Security Council at its 6984th meeting, on 24 June 2013, Resolution 2122 (2013), adopted by the Security Council at its 7044th meeting, on 18 October 2013, Resolution 2242 (2015), adopted by the Security Council at its 7533rd meeting, on 13 October 2015.

\footnotetext{
${ }^{5}$ Resolution 1325 (2000) Adopted by the Security Council at its 4213th meeting, on 31 October 2000. Retrieved from https://documents-dds-ny.un.org/doc/UNDOC/GEN/N00/720/18/ PDF/N0072018.pdf?Open Element
} 


\section{Sustainable Development Goals (SDGs)}

On 1 January 2016, the 17 Sustainable Development Goals (SDGs) of the 2030 Agenda for Sustainable Development - adopted by world leaders in September 2015 at an historic UN Summit - officially came into force. Over the next fifteen years, with these new Goals that universally apply to all, countries will mobilize efforts to end all forms of poverty, fight inequalities and tackle climate change, while ensuring that no one is left behind ${ }^{6}$.

The SDGs, also known as Global Goals, build on the success of the Millennium Development Goals (MDGs) and aim to go further to end all forms of poverty. The new Goals are unique in that they call for action by all countries, poor, rich and middle-income to promote prosperity while protecting the planet. They recognize that ending poverty must go handin-hand with strategies that build economic growth and addresses a range of social needs including education, health, social protection, and job opportunities, while tackling climate change and environmental protection.

While the SDGs are not legally binding, governments are expected to take ownership and establish national frameworks for the achievement of the 17 Goals. Countries have the primary responsibility for follow-up and review of the progress made in implementing the Goals, which will require quality, accessible and timely data collection. Regional follow-up and review will be based on national-level analyses and contribute to follow-up and review at the global level.

The European Union (EU) and the United Nations (UN) are embarking on a new, global, multi-year initiative focused on eliminating all forms of violence against women and girls (VAWG) - the Spotlight Initiative. The Initiative is so named as it brings focused attention to this issue, moving it into the spotlight and placing it at the centre of efforts to achieve gender equality and women's empowerment, in line with the 2030 Agenda for Sustainable Development ${ }^{7}$.

An initial investment in the order of EUR 500 million will be made, with the EU as the main contributor. Other donors and partners will be invited to join the Initiative to broaden its reach and scope.

\footnotetext{
6 The Sustainable Development Agenda. Retrieved from http://www.un.org/sustainabledevelopment/ development-agenda/

Goal 5: Achieve gender equality and empower all women and girls. Retrieved from http://www.un.org/sustainabledevelopment/gender-equality/
} 
Facts and figures: 1) about two thirds of countries in the developing regions have achieved gender parity in primary education; 2) in Southern Asia, only 74 girls were enrolled in primary school for every 100 boys in 1990. By 2012, the enrolment ratios were the same for girls as for boys; 3 ) in sub-Saharan Africa, Oceania and Western Asia, girls still face barriers to entering both primary and secondary school; 4) women in Northern Africa hold less than one in five paid jobs in the non-agricultural sector. The proportion of women in paid employment outside the agriculture sector has increased from 35 percent in 1990 to 41 percent in 2015 ; 5) in 46 countries, women now hold more than 30 percent of seats in national parliament in at least one chamber.

Goal 5 targets:

1) end all forms of discrimination against all women and girls everywhere;

2) eliminate all forms of violence against all women and girls in the public and private spheres, including trafficking and sexual and other types of exploitation;

3) eliminate all harmful practices, such as child, early and forced marriage and female genital mutilation;

4) recognize and value unpaid care and domestic work through the provision of public services, infrastructure and social protection policies and the promotion of shared responsibility within the household and the family as nationally appropriate;

5) ensure women's full and effective participation and equal opportunities for leadership at all levels of decisionmaking in political, economic and public life;

6) ensure universal access to sexual and reproductive health and reproductive rights as agreed in accordance with the Programme of Action of the International Conference on Population and Development and the Beijing Platform for Action and the outcome documents of their review conferences;

7) undertake reforms to give women equal rights to economic resources, as well as access to ownership and control over land and other forms of property, financial services, inheritance and natural resources, in accordance with national laws;

8) enhance the use of enabling technology, in particular information and communications technology, to promote the empowerment of women; 
9) adopt and strengthen sound policies and enforceable legislation for the promotion of gender equality and the empowerment of all women and girls at all levels.

\section{Policy of the North Atlantic Treaty Organization}

Today is recognising the important and distinctive role that women play in conflict resolution and peace settlement. NATO's mission is to contribute to sustainable and lasting peace, within which gender equality and empower all women and girls is a key factor. The North Atlantic Alliance seeks including the gender dimension in all stages of the operational process - in the design, planning, implementation, monitoring and evaluation of policies and programmes.

The North Atlantic Alliance underlines the essential role of women in the prevention of conflict, as well as in post-conflict peace building and reconstruction efforts. It aims at the integration of gender considerations into all aspects of security work. This includes participation in conflict resolution and peace processes, peacekeeping operations, disarmament, demobilisation and reintegration, security sector reform, protection and rights of women. It also encourages increased representation of women at all decision-making levels in national, regional and international institutions, as well as consultation with local and international women's groups.

NATO is an alliance of countries from Europe and North America. It provides a unique link between these two continents, enabling them to consult and cooperate in the field of defence and security, and conduct multinational crisis-management operations together. The most important players in the North Atlantic Treaty Organization are the member countries themselves. NATO membership is open to "any other European state in a position to further the principles of this Treaty and to contribute to the security of the North Atlantic area." NATO is committed to the principle that an attack against one or several of its members is considered as an attack against all. This is the principle of collective defence, which is enshrined in Article 5 of the Washington Treaty. So far, Article 5 has been invoked once - in response to the 9/11 terrorist attacks in the United States in $2001^{8}$.

\footnotetext{
${ }^{8}$ WHAT IS NATO? URL: https://www.nato.int/nato-welcome/index.html\#.
} 
Security in our daily lives is key to our well-being. NATO's purpose is to guarantee the freedom and security of its members through political and military means. POLITICAL - NATO promotes democratic values and enables members to consult and cooperate on defence and securityrelated issues to solve problems, build trust and, in the long run, prevent conflict.

Every day, member countries consult and take decisions on security issues at all levels and in a variety of fields. A "NATO decision" is the expression of the collective will of all 29 member countries since all decisions are taken by consensus. Hundreds of officials, as well as civilian and military experts, come to NATO Headquarters each day to exchange information, share ideas and help prepare decisions when needed, in cooperation with national delegations and the staff at NATO Headquarters.

The North Atlantic Alliance partnership with the United Nations for peace and security

Around 40 non-member countries work with NATO on a wide range of political and security-related issues. These countries pursue dialogue and practical cooperation with the Alliance and many contribute to NATO-led operations and missions. NATO is also cooperating with a wide network of international organisations.

NATO's partnership with the UN is also a central one due to the role played by that body within the world system and by the Allies' pledge of faith (invoked in the preamble to the North Atlantic Treaty) "in the purposes and principles of the Charter of the United Nations." The Security Council's mandate - to safeguard international security and peace - meshes well with the commitment of NATO members to "unite their efforts for collective defence and for the preservation of peace and security." It is clearly in NATO's interests to support the UN and to help strengthen its capacity to perform the many missions assigned to it by the global community'.

North Atlantic Treaty Organization and the UN have worked together in a number of conflict zones, with the Alliance providing operational support and security so that the UN can move ahead on reconstruction, development, and governance-building. Although their partnership dates

\footnotetext{
9 Nato 2020: assured security; dynamic engagement. URL: https://www.nato.int/nato_static_fl2014/ assets/pdf/pdf_2010_05/20100517_100517_expertsreport.pdf.
} 
back more than a decade - and while NATO and the UN signed a framework agreement in 2008 which has improved practical cooperation in some cases - problems remain. UN personnel have been disappointed, on occasion, with the level of security and support that NATO provides. NATO tends to wait until a mission begins before starting to coordinate with the UN.

In a world of global threats, security depends increasingly on a rulebased international order. One of NATO's priorities, therefore, should be to strengthen the ability of the United Nations to fulfil its responsibilities. NATO should work with the UN to respond positively to Security Council Resolution 1325, concerning the role of women in security and peace.

The North Atlantic Alliance and its partners are taking action to promote the role of women in peace and security. This demonstrates their commitment to support the implementation of United Nations Security Council Resolution (UNSCR) 1325 and related Resolutions (1820, 1888, 1889, 1960, 2106, 2122 and 2422). These Resolutions recognise the disproportionate impact that war and conflict has on women and children and highlight the fact that historically women have been left out of peace processes and stabilisation efforts. They call for full and equal participation of women at all levels ranging from conflict prevention to post-conflict reconstruction, peace and security. They call for the prevention of sexual violence and accountability to end impunity for incidents of sexual violence in conflict. Together, these resolutions frame the Women, Peace and Security agenda ${ }^{10}$.

The Alliance and its partners are committed to removing barriers for women's participation in the prevention, management and resolution of conflicts and in peace-building, and to reducing the risk of conflict-related and gender-based violence. NATO Allies and partners in the EuroAtlantic Partnership Council (EAPC) launched work in this area in 2007 with the adoption of a specific policy to support implementation of UNSCR 1325.

Over the years, the policy has been updated, related action plans have strengthened implementation and more partner countries from around the globe have become associated with these efforts. At the 2014 Wales Summit, Allied leaders acknowledged that the integration of gender

\footnotetext{
${ }^{10}$ Women, Peace and Security. URL: https://www.nato.int/ cps/en/natohq/topics_91091.htm?selected Locale $=\mathrm{en}$.
} 
perspectives throughout NATO's three essential core tasks (i.e. collective defence, crisis management and cooperative security) will contribute to a more modern, ready and responsive NATO. Gender is an important focus of NATO's cooperation with other international organizations - in particular the United Nations - and civil society.

NATO is also taking action within its own organisation and structures to promote gender equality and the participation of women. The NATO Secretary General has appointed a Special Representative to serve as the high-level focal point on all aspects of NATO's contributions to the Women, Peace and Security agenda.

According to the United Nations, before the Second World War, 90 percent of casualties in conflicts were combatants. Today, the majority of casualties are civilians, especially women and children. Not only are their needs ignored during times of conflict, but women are often excluded from efforts to make and keep the peace - despite representing half the population. The continued under-representation of women in peace processes, the lack of institutional arrangements to protect women and the widespread use of sexual- and gender-based violence as a tactic of war, remain major impediments to building sustainable peace.

At the multilateral level, NATO and its Partners have joined a number of International Organisations, such as the EU and the OSCE, in contributing to the international community's efforts in support of the principles of UNSCR 1325 and its related Resolutions, and have advocated a broad approach to this global issue in the security field. There is increasing recognition that women have a crucial role to play and special skills to contribute to dealing successfully with the security challenges of the 21 st century ${ }^{11}$.

The UN Security Council called on the international community to take action to address these issues through UNSCR 1325, adopted on 31 October 2000, which was followed by seven additional Resolutions $(1820,1888,1889,1960,2106,2122$ and 2422). NATO is actively seeking to incorporate gender perspectives within the analysis, planning, execution and evaluation of its operations and missions. These efforts increase operational effectiveness and have already made a tangible difference to the lives of women in Afghanistan and in the Balkans.

\footnotetext{
${ }^{11}$ Comprehensive report on the NATO/EAPC policy on the implementation of UNSCR 1325 on women, peace and security and related resolutions. URL: http://sedici.unlp.edu.ar/bitstream/handle/ 10915/44524/NATO_-_Comprehensive_report_on_the_NATO_EAPC_policy_on..._11_p._.pdf?sequence=78
} 
Gender-related issues are an important focus of work in NATO's cooperation with partner countries, both in the preparation of troops that will deploy in NATO-led operations and in wider cooperation on defence capacity building. Such initiatives are already bearing fruit. For example, a Trust Fund project in Jordan supports the development of service women in the Jordanian Armed Forces through improved training facilities, enhanced education and training material and policy initiatives. Some of the country's women soldiers were deployed as female engagement teams as part of the NATO-led operation in Afghanistan.

The North Atlantic Alliance and its partners' active commitment to UNSCR 1325 and related Resolutions resulted in a formal NATO/EAPC policy to support the implementation of these Resolutions, first issued in December $2007^{12}$.

A first action plan to mainstream UNSCR 1325 and related Resolutions into NATO-led operations and missions was endorsed at the Lisbon Summit in November 2010 on the occasion of the tenth anniversary of UNSCR 1325.

The policy and action plan were revised in 2014. This paved the way for more practical cooperation with NATO's broad partnership network beyond the EAPC framework. In total 56 Allies and partners signed up to their implementation. Afghanistan, Australia, Japan, Jordan and the United Arab Emirates participated actively in their development, and New Zealand later associated itself with this effort too. Progress reports are issued every six months. The policy is based on the key pillars of UNSCR 1325: participation of women in conflict prevention, management and resolution; women's participation in peace-building; protection of women's and girls' rights; and prevention of conflict-related sexual- and gender-based violence. The policy draws on both internal and external NATO resources for implementation.

NATO's fundamental and enduring purpose is to safeguard the freedom and security of all its members by political and military means. In accordance with NATO's Strategic Concept, this will be done through its three essential core tasks of collective defence, crisis management and

\footnotetext{
12 RECOMMENDATIONS ON IMPLEMENTATION OF UNSCR 1325 . URL: https://www.nato.int/issues/women_nato/pdf/2010/BrochureGender.pdf;

On approval of the national plan of action for the implementation of UN Security Council resolution 1325 women, peace, security for the period to 2020 year: Ordinance of the Cabinet of Ministers of Ukraine of 24.02.2016 № 113-r. URL : http://zakon3. rada . gov . ua / laws / show /113-2016-\% D 1\%80/ page
} 
cooperative security. Within the context of NATO's wider policy objectives and core tasks, NATO will continue to integrate a gender perspective into its work and contribute to the implementation of UNSCR 1325 and related Resolutions ${ }^{13}$.

The North Atlantic Alliance and its partners aim to contribute to the full implementation of the UN Security Council Resolutions on Women, Peace and Security by making this Policy an integral part of their everyday business in both civilian and military structures. NATO and its partners aim to ensure that a gender perspective is mainstreamed into policies, activities and efforts to prevent and resolve conflicts. Due regard will be given to the social roles of both men and women and how these may lead to different risks and security needs. Attention will also be paid to how these roles may translate into different contributions to conflict prevention and resolution. NATO and its partners aim to yield a change in mind sets and behaviours in their institutions and promote awareness and positive changes.

The two Strategic Outcomes aimed for in this Action Plan follow two main tracks; one for the participation of women and the other of integration and institutionalization of gender perspectives. All actions are to support these Strategic Outcomes: 1. reduced barriers for the active and meaningful participation of Women in NATO's, Allies' and partners' defence and security institutions, and within NATO-led operations, missions and crisis management; 2 . Women, Peace and Security priorities and a gender perspective are integrated in policies, activities and efforts under-taken by NATO, Allies and partners to prevent and resolve conflicts. The period to be covered is two years, from June 2016 June 2018.

In line with the policy, the action plan concentrates on 14 outcomes and several actions, whose implementation and responsibility are shared between NATO International Staff, NATO Military Authorities and relevant national authorities.

Other cross-cutting aspects, such as human resources policies, education, training and exercises and public diplomacy, are also addressed and play an important role in enhancing the policy's implementation within the Alliance.

\footnotetext{
${ }^{13}$ NATO/EAPC ACTION PLAN FOR THE IMPLEMENTATION OF THE NATO/EAPC POLICY ON WOMEN PEACE AND SECURITY. URL: https://www.nato.int/nato_static_fl2014/ assets/pdf/pdft_2016_07/160718-wps-action-plan.pdf.
} 
In the context of their partnership programmes with NATO, partners are encouraged to adopt specific goals that reflect the principles and support implementation of UNSCR 1325 and related Resolutions. They are also encouraged to make use of the training and education activities developed by Allied Command Transformation, which has ensured that a gender perspective is included in the curriculum of NATO Training Centres and Centres of Excellence as well as in pre-deployment training.

Though the Alliance has no influence on measures or policies taken at national levels, it is required that all personnel - whether from Allied or partner countries - deployed in NATO-led operations and missions and serving within NATO structures are appropriately trained and meet required standards of behaviour.

Work among Allies and partner countries is not only about developing gender awareness in crisis-management or peace-support operations. An increasingly important focus is on strengthening gender perspectives, and promoting gender equality and the participation of women in defence and security institutions as well as the armed forces.

UNSCR 1325 and related Resolutions are also being implemented in crisis management and in NATO-led operations and missions. The Alliance has nominated gender advisers at both Strategic Commands Allied Command Operations and Allied Command Transformation - as well as in subordinate commands and the operations in Afghanistan and Kosovo. Gender advisors support commanders to ensure that a gender perspective is integrated into all aspects of an operation. An important milestone was reached in May 2015, when NATO's first ever female Commander was appointed to NATO's headquarters in Sarajevo, Bosnia and Herzegovina.

Along with having more female personnel on the ground, these measures have had a positive effect on the implementation of UNSCR 1325 in theatres of operation. For instance, in Afghanistan, female soldiers are able to connect with members of the population otherwise closed off from their male colleagues. Gender advisers have also sought to promote public awareness and ensure that the gender perspective is incorporated in operational planning documents throughout the chain of command, as well as in documents outlining NATO's current and future partnership with Afghanistan. 
In 2014, the Special Representative for Women, Peace and Security and the Human Resource Policy and Diversity Officer launched the NATO Women's Professional Network (NWPN) and Mentoring Programme. The aim of the NWPN is to promote a common corporate culture and give training, development and mentoring opportunities to women. The Mentoring Programme seeks to help increase the pool of qualified female candidates and to break down structural barriers that may exist between different services and types of staff.

In 2015, NATO and its partners adopted, for the first time, Military Guidelines on the protection of, and response to, conflict-related sexualand gender-based violence. Gender-related issues are also increasingly being incorporated in exercises. For example, NATO's Crisis Management Exercise in 2015 included - for the first time ever - a gender perspective as one of its objectives. These annual exercises are designed to practise the Alliance's crisis management procedures at the strategic political level, and involve civilian and military staffs in Allied capitals, at NATO Headquarters, and in both Strategic Commands.

The implementation of UNSCR 1325 and related Resolutions cuts across various divisions and governing bodies within NATO Headquarters, as well as in the Strategic Commands. All these entities together are responsible for monitoring and reporting the progress made by the Alliance. For this purpose, a Women, Peace and Security Task Force was established under the guidance and responsibility of the Special Representative for Women, Peace and Security. A specific body was also set up to advise the Military Committee.

In sum, the mechanisms at NATO's disposal to implement the UNSC Resolutions are:

1. The Secretary General's Special Representative for Women, Peace and Security serves as the high-level focal point on all aspects of NATO's gender-related work. This position was created in 2012, and made permanent from September 2014. It is currently held by Clare Hutchinson;

2. A task force bringing together civilian and military staff across the Headquarters;

3. A gender office (NATO Office on Gender Perspectives) and an advisory committee of experts (NATO Committee on Gender Perspectives) on the military side, tasked with promoting gender 
mainstreaming in the design and implementation, monitoring and evaluation of policies, programmes and military operations;

4. A working group led by Allied Command Operations to assess means to further incorporate UNSCR 1325 and related Resolutions into operational planning and execution;

5. Gender advisers deployed at different levels of NATO's military command structure, including operational headquarters;

6. A number of relevant committees that develop and review specific and overall policy;

7. The NATO Science for Peace and Security (SPS) Programme promotes concrete, practical cooperation on gender-related issues among NATO member and partner countries, through collaborative multi-year projects, training courses, study institutes and workshops.

\section{CONCLUSIONS}

The United Nations has adopted a number of resolutions that consolidate the main provisions to overcome gender inequality, which, although advisory, are widely implemented in the national legislation of the countries of the world.

Obvious is that for the United Nations gender equality and empower all women and girls is one of the priorities goals. This is an international organization urges Member States to ensure increased representation of women at all decision-making levels in national, regional and international institutions and mechanisms for the prevention, management, and resolution of conflict for peace and security. Cooperating with the European Union, the United Nations are embarking multi-year initiative focused on eliminating all forms of violence against women and girls, in line with the 2030 Agenda for Sustainable Development.

NATO is working with the United Nations and taking steps to promote gender equality and empower all women and girls to identify and remove barriers to women within NATO's policies and programmes. The North Atlantic Alliance sought to ensure equal participation of women at all levels ranging from conflict prevention to post-conflict reconstruction, peace and security, in attract and retain women, especially in senior leadership positions, the prevention of sexual violence and accountability 
to end impunity for incidents of sexual violence in conflict, reflect principles by UNSCR 1325 and related Resolutions.

Consequently, in the process of solving the issue of gender equality and empower all women and girls in the sphere of peace and security, not only the state but also international organizations involved in the formation and improvement of the national legal mechanism for ensuring the rights of every person irrespective of gender, provide recomendation on implementation the best world experience, exercising supervision and control.

\section{REFERENCES}

1. Overview. Retrieved from http://www.un.org/en/sections/aboutun/overview/index.html

2. The United Nations Today. Retrieved from http://www.un.org/ar/ geninfo/pdf/UN.today.pdf

3. Protect Human Rights. Retrieved from http://www.un.org/en/ sections/what-we-do/protect-human-rights/

4. Gender equality: why it matters. Retrieved from http://www.un.org/sustainabledevelopment/wpcontent/uploads/2016/08/5_Why-it-Matters_GenderEquality_2p.pdf

5. Resolution 1325 (2000) Adopted by the Security Council at its 4213th meeting, on 31 October 2000. Retrieved from https://documentsdds-ny.un.org/doc/UNDOC/GEN/N00/720/18/PDF/

N0072018.pdf?OpenElement

6. The Sustainable Development Agenda. Retrieved from http://www.un.org/sustainabledevelopment/development-agenda/

7. Goal 5: Achieve gender equality and empower all women and girls. Retrieved from http://www.un.org/sustainabledevelopment/genderequality/

8. What is NATO? URL: https://www.nato.int/natowelcome/index.html\#.

9. Nato 2020: assured security; dynamic engagement. URL: https://www.nato.int/nato_static_fl2014/assets/pdf/pdf_2010_05/2010051 7_100517_expertsreport.pdf.

10. Women, Peace and Security. URL: https://www.nato.int/cps/en/ natohq/topics_91091.htm?selectedLocale=en. 
11. Comprehensive report on the NATO/EAPC policy on the implementation of UNSCR 1325 on women, peace and security and related resolutions. URL: http://sedici.unlp.edu.ar/bitstream/handle/ 10915/44524/NATO_-_Comprehensive_report_on_the_ NATO_EAPC_policy_on...__11_p._.pdf?sequence $=78$.

12. Recommendations on implementation of UNSCR 1325. URL: https://www.nato.int/issues/women_nato/pdf/2010/BrochureGender.pdf.

13. NATO/EAPC action plan for the implementation of the NATO/EAPC policy on women peace and security. URL: https://www.nato.int/nato_static_fl2014/assets/pdf/pdft_2016_07/160718wps-action-plan.pdf.

14. On approval of the national plan of action for the implementation of UN Security Council resolution 1325 women, peace, security for the period to 2020 year: Ordinance of the Cabinet of Ministers of Ukraine of 24.02.2016 № 113-r. URL : http://zakon3. rada . gov . ua / laws / show /113-2016-\% D 1\%80/ page .

15. Nalyvaiko 1., Witwicki recreated s. Law on access to public information in the context of the control of citizens over the activities of the State . Law and society . 2014 . №2.

16. Камінська Н.В. Правозахисна діяльність міжнародних європейських організацій. Правовий захист прав людини та громадянина в Україні : зб. матер. всеукр. наук.-теорет. конф., 24 листопада 2011, м. Київ. - К., 2011. - С. 21-23.

17. Камінська Н.В., Бреус С. М. Реалізація права на тендерну ідентичність в Україні та Російській Федерації: наслідки авторитарної ідеології чи національний консерватизм?: Форум права. 2014. № 1. С. 203-208. Режим доступу: http://nbuv. gov.ua/ j-pdf/FP_index.htm_2014_1_36.pdf

18. Равлінко 3.П. Заборона дискримінації: загальнотеоретичне дослідження: дисертація на здобуття наукового ступеня кандидата юридичних наук спеціальність: 12.00.01 - теорія та історія держави і права; історія політичних і правових учень. Л., 2016

19. Kaminska, N.; Romanova, N. Глобальні завдання ОOH у сфері гендерної рівності. The United Nations worldwide goal: achieve gender equality and empowe http://elar.naiau.kiev.ua/jspui/handle/123456789/ 5196 
20. Kaminska N., Romanova N. The United Nations worldwide goal: achieve gender equality and empower. Гендерна політика ООН на межі XX-XXI ст. Юридичний часопис Наи. акад. внутр. справ. 2017. № 2. C.386-395

21. Камінська Н.В., Романова Н.В. Реалізація політики гендерної рівності оон в секторі безпеки і оборони України. Стан та перспективи реформування сектору безпеки $і$ оборони Украӥни Матеріали міжнародної науково-практичної конференція, 30 листопада 2018 року (Управління державної охорони України в Київському національного університеті імені Тараса Шевченка). URL: http://www.indo.knu.ua/index.php/ua/

22. Тематична доповідь Європейського комісара 3 прав людини Ради Європи: «Права людини та гендерна ідентичність» від 29 липня 2009 p. [Електронний ресурс]. - Режим доступу: https://wcd.coe.int/ ViewDoc.jsp?id $=1588227 \&$ Site $=\mathrm{COE}$

23. Камінська Н., Романова Н. Діяльність Організації з безпеки i співробітництва в Європі у сфері гендерної рівності Правові засади європейської та євроатлантичної інтеграції Украӥни: досягнення та перспективи: матеріали учасників II-ої заочної науково-практ. конференції (Львів, 23 листопада 2018 року). Львів: ННІПП НУ «Львівська Політехніка», 2018. С. 144-147/

\section{Information about the author Kaminska N. V. Doctor of Law, Professor,} Professor at the Department of Constitutional Law and Human Rights of the National Academy of Internal Affairs 1, Solomianska pl., Kyiv, 03035, Ukraine 